\title{
Connectivity Characteristics and Level of Acceptance Linked to Online Learning by Higher Education Students During the Confinement Generated by the Covid-19 Pandemic
}

\author{
Holman Montiel Ariza ${ }^{1}$, Fredy H. Martínez Sarmiento² and Harvey Gómez Castillo ${ }^{3}$ \\ Associates Professors, Facultad Tecnológica, Universidad Distrital Francisco José de Caldas, Bogotá D.C, Colombia.
}

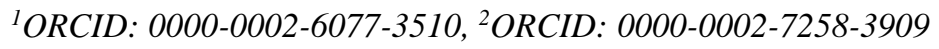

${ }^{3}$ ORCID: 0000-0003-4474-3642

\begin{abstract}
Online education was the alternative used worldwide to provide continuity with training processes in higher education institutions during the confinement generated by the Covid-19 pandemic. The objective of this work is to analyze and identify the characteristics of connectivity and the level of acceptance linked to online learning by students of technological programs at the Universidad Distrital Francisco José de Caldas. For this purpose, 287 students from 3 different academic programs were surveyed, where it was possible obtain information on Internet connectivity, positive and negative impressions associated with the digital tools they were using in their classes and finally the perception of the accompaniment of their teachers in the training processes.
\end{abstract}

Keywords: Online Learning, Digital Divide, Covid-19, Confinement, Technology Education.

\section{INTRODUCTION}

Thanks to new technologies and digital tools, both at a hardware level (smartphones, tablets, laptops, etc.) and at a software level (learning platforms, course management systems - CMS, repositories, massive open online courses - MOOCs, simulators, etc.) and connectivity that allows digital ubiquity, formal education institutions have begun to integrate concepts such as smart learning environments, smart e-learning or smart classroom into their training strategies (Ospina, \& Galvis, 2017). These strategies, although in continuous evolution, have made it possible to shape what has been called the Smart University (SmU) (Tikhomirov, Dneprovskaya, \& Yankovskaya, 2015). These ideas have become even more important today due to the restrictions on mobility and social interaction imposed worldwide by the spread of the COVID-19 virus (Connor et al., 2020; Huang, Liu, Tlili, Yang, \& Wang, 2020).

These new social conditions have forced universities and institutes of higher education in a very short time to strengthen their distance training strategies, pushing teachers and students into new educational normality that abruptly breaks with the pre-confinement dynamic. In many cases, these online learning environments were only used by teachers as non-essential support tools, but now they have become the basic platforms of the training process (Mesiono, 2020; Winarso, Yuliana, Muniroh, Halin, \& Tyas, 2020).
Remote learning environments have special characteristics that allow the creation of unique conditions and opportunities in the academic development of students and teachers, in aspects such as personalized learning, new learning, and teaching strategies, greater focus and motivation of students, more targeted interaction between students and teachers, design and development of interactive learning content on the Internet, development of multimedia material (mainly videos), and evaluation and immediate feedback, among others. Besides, they allow access to specific material in many ways, which is particularly important with students with low economic resources and/or technological difficulties (Mulenga \& Marbán, 2020). Other positive impacts not related to the education process involve the safety of the academic community (in particular concerning COVID-19), environmental protection (related to digital management and reduced mobility), and simplification of some administrative processes (Favale, Soro, Trevisan, Drago, \& Mellia, 2020).

A comprehensive training process must include elements such as critical thinking, awareness, logical reasoning, self-learning, adaptation, communication, and integrated work. Some of these elements are supported in remote environments, even better managed than in a classroom setting. However, the abrupt change from a face-to-face to a distance mode significantly affects students and teachers at a social and emotional level (Abuhassna, Zakaria, Yahya, Kosnin, \& AlRahmi, 2020). In this context, teachers must promote aspects such as collaborative work, motivation to the learning process, identification and support of students with specific difficulties, and most importantly, to provide feedback to the student, which is essential to build confidence. Also, the new distance model assumes that both have technological capacity related to the availability of devices/connection and digital management skills, which from experience has been observed does not coincide with the reality (Garcia, Corell, Abella, \& Grande, 2020).

One of the most important strengths of learning environments supported by online technology is their ability to empower students. Under this model the teacher ceases to be a totalitarian authority, giving the student the capacity to apply his learning strategy, at his own pace, and according to his time and resource conditions (Starr-Glass, 2020). The role of the teacher becomes that of a designer of the training strategies based on the objectives of the course, of a counselor in the process and application of the training strategies, of feedback and support 
in the process of the students in coherence with their needs.

While it is true that online training strategies have a strong democratizing character of education by allowing a greater level of access and opportunity of study to a larger number of students, it is also true that this type of training presents many more challenges to the student and teacher (Aikina \& Bolsunovskaya, 2020; Israfilov et al., 2020). The design of the material and other elements of the course cannot cover the wide range of learning schemes and processes present in the students, which is why it is necessary to provide a greater and different level of support from teachers (He, Zheng, Di, \& Dong, 2019). It has been observed that students do not use critical selfregulated learning (SRL), an element that has been identified as fundamental in learning processes based on online environments (Wong et al., 2019). Research has pointed out that these difficulties by the student possibly explain the high rates of student dropout reported by the online models (Ejubović \& Puška, 2019; Muljana \& Luo, 2019).

Online learning environments tend to significantly reduce social interaction between students. However, this is a crucial element in the training process that should be encouraged (Hussin, Harun, \& Shukor, 2019a, 2019b). Interaction between students promotes critical thinking, involving participants even more in the learning activity, which in turn increases the levels of personal commitment to the course, peers, and teacher (Im \& Kang, 2019). It is widely accepted that critical thinking in vocational training is fundamental to increasing the social impact of future professional (Azhari et al., 2020). This can be encouraged by proposing and supporting activities that involve higher order thinking in the solution of problems with a high social impact (Zalli, Nordin, \& Hashim, 2020).

\section{MATERIALS AND METHODS}

The development of this research was carried out with a survey method whose primary objective was to identify the connectivity characteristics and level of acceptance associated with online education during the quarantine generated by the Covid-19 pandemic. A sample of 287 students belonging to 3 study programs (Technology in electronics, Technology in medium and low voltage electrical systems and Control Engineering) from the Universidad Distrital Francisco José de Caldas, Bogotá-Colombia was counted. See Table 1.

Table 1. Biographical data of students surveyed online

\begin{tabular}{|c|c|c|c|}
\hline $\begin{array}{l}\text { Classification of } \\
\text { respondents }\end{array}$ & Category & Percentage & $\begin{array}{l}\text { Number of } \\
\text { respondents }\end{array}$ \\
\hline \multirow{2}{*}{ Gender } & Female & $84,0 \%$ & 241 \\
\hline & Male & $16,0 \%$ & 46 \\
\hline \multirow{5}{*}{ Socioeconomic } & 1 & $16,0 \%$ & 46 \\
\hline & 2 & $62,0 \%$ & 178 \\
\hline & 3 & $21,4 \%$ & 61 \\
\hline & 4 & $0,3 \%$ & 1 \\
\hline & 5 & $0,3 \%$ & 1 \\
\hline \multirow{10}{*}{ Semester } & 1 & $34,5 \%$ & 99 \\
\hline & 2 & $13,2 \%$ & 38 \\
\hline & 3 & $11,5 \%$ & 33 \\
\hline & 4 & $10,1 \%$ & 29 \\
\hline & 5 & $10,5 \%$ & 30 \\
\hline & 6 & $11,1 \%$ & 32 \\
\hline & 7 & $3,5 \%$ & 10 \\
\hline & 8 & $1,4 \%$ & 4 \\
\hline & 9 & $3,1 \%$ & 9 \\
\hline & 10 & $1,1 \%$ & 3 \\
\hline \multirow{4}{*}{ Ages } & between 16 - 18 years old & $35,5 \%$ & 102 \\
\hline & between $19-21$ years old & $46,0 \%$ & 132 \\
\hline & between $22-25$ years old & $15,0 \%$ & 43 \\
\hline & $>25$ years old & $3,5 \%$ & 10 \\
\hline
\end{tabular}


The survey consisted of 23 closed-ended questions that described: the characteristics of the equipment most used by the students to approach the online classes, the quality associated with the Internet connectivity in their homes, the positive and negative impressions associated with the digital tools they were using in their classes and finally the perception about the accompaniment of their teachers in the training processes.

\section{RESULTS AND DISCUSSION}

The first part of the instrument created for the survey focuses on collecting all the information associated with the devices used in the Teaching-Learning process; this part focused on analyzing the type of device used and the characteristics of the Internet connectivity of the respondents' households.

Fig. 1 shows that conventional computer equipment such as desktops and laptops are still the most widely used devices by students, overall, $63.6 \%$ of respondents use these devices. However, the next most used item is the smartphone with $31.9 \%$, an indicator that shows us that this element becomes fundamental in the daily life of university students.



Fig. 1. Respondents' response to the question What type of device do you often use for classes?

Fig. 2 shows the analysis of the characteristics associated with the performance aspects of the devices used by the students; it should be taken into account that, for the most part, these are devices that the student already had in his or her possession and are being used to address the situation presented by the mandatory quarantine decreed by government entities and following the guidelines of the Colombian Ministry of Education.

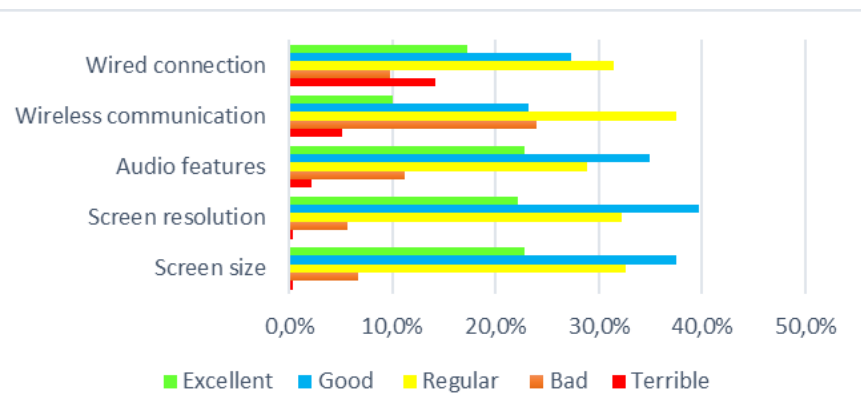

Fig. 2. Respondents' response on rating aspects of the device used during online learning.
Fig. 3 shows that many students do not have a broadband connection for Internet service, since according to the Communications Regulation Commission of the Republic of Colombia, broadband services must have a minimum speed of $25 \mathrm{Mbps}$ downstream and $5 \mathrm{Mbps}$ upstream.

In addition to the factor mentioned above, the quality of service provided by Internet Service Providers is not good, there is a $63.9 \%$ disagreement associated with the frequency of lost connectivity with this service, see Fig. 4 and 5.

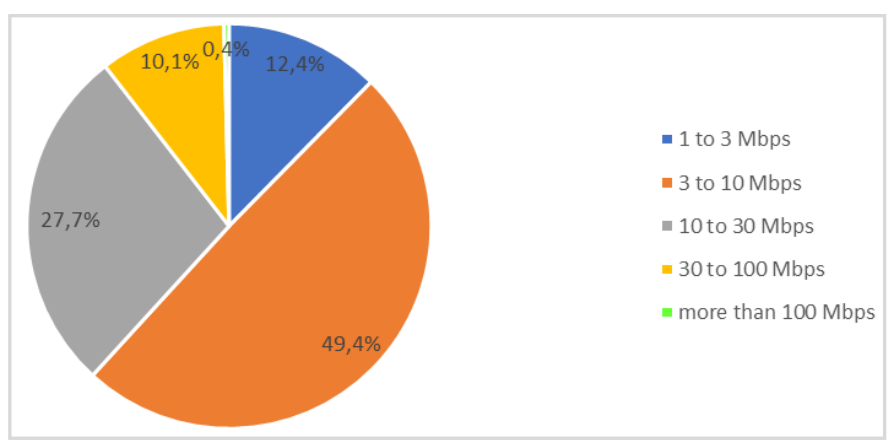

Fig. 3. Respondents' response to the question What is the bandwidth of their Internet connection?

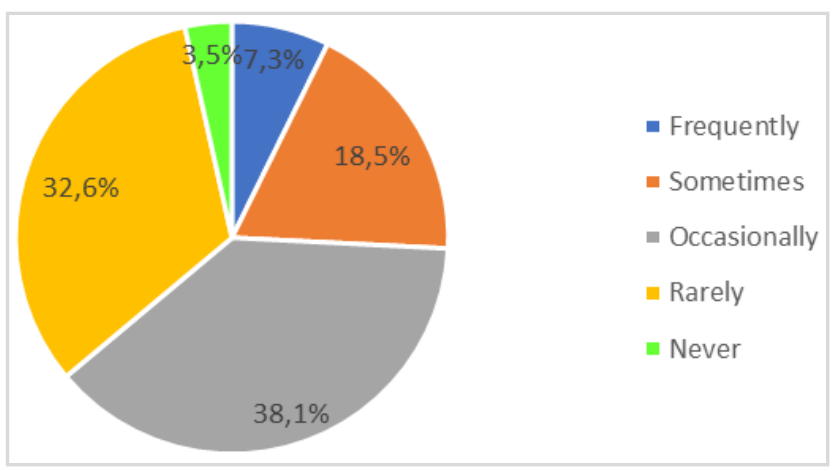

Fig. 4. Respondents' response to the question How often is connectivity lost?

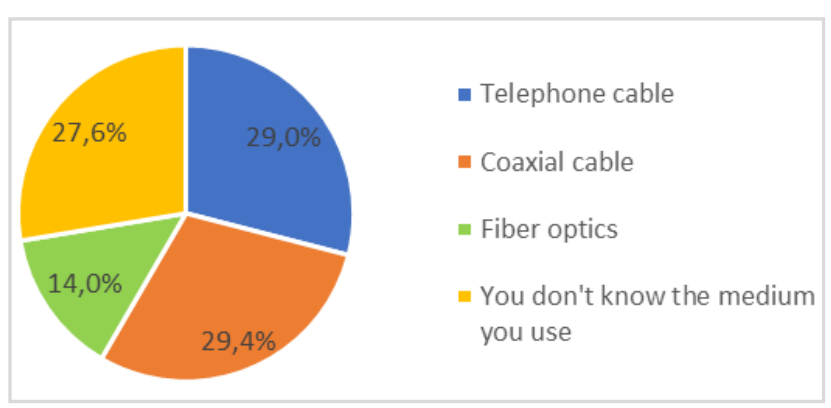

Fig. 5. Respondents' response to the question What type of connection media do you use to connect to the Internet? (Connection provided by the Internet Service Provider).

While it is true that many students are adapting to the process of remote learning, a key factor in assessing and analyzing the characteristics of connectivity would be the number of people 
International Journal of Engineering Research and Technology. ISSN 0974-3154, Volume 13, Number 8 (2020), pp. 1934-1939

(C) International Research Publication House. https://dx.doi.org/10.37624/IJERT/13.8.2020.1934-1939

in the household who make use of the Internet connection. Table 2 shows that due to issues of compulsory quarantine and teleworking in some cases, the bandwidth would be seriously compromised according to the number of users with whom the connection is shared simultaneously.

Table 2. Number of people who are simultaneously connected in your home to study, work or develop another activity

\begin{tabular}{|c|c|}
\hline $\begin{array}{c}\text { Number of } \\
\text { people }\end{array}$ & Percentage \\
\hline 0 & $1,1 \%$ \\
\hline 1 & $2,8 \%$ \\
\hline 2 & $12,8 \%$ \\
\hline 3 & $23,9 \%$ \\
\hline 4 & $15,0 \%$ \\
\hline 5 & $8,9 \%$ \\
\hline 6 & $3,3 \%$ \\
\hline 7 & $4,4 \%$ \\
\hline 8 & $1,1 \%$ \\
\hline 9 & $1,1 \%$ \\
\hline 10 & $100,0 \%$ \\
\hline
\end{tabular}

The second part of the survey focused on collecting all the information related to the aspects of favorability and acceptance towards the e-learning process. The digital tools they use in their training process and the students' perception of the teachers' accompaniment of this learning methodology were analyzed.

According to the diagrams in Fig. 6, 79.1\% of the students present dissatisfaction with the tools of a single application or use, such as the case of Zoom; there is a high acceptance for the case of integrated services within the same environment, as is the case of the Google educational platform.



Fig. 6. Respondents' response on rating the digital tools they use in their Teaching-Learning process
The process of communication and interaction in the online learning environment is a fundamental factor to help students achieve better results, Fig. 7 shows with respect to communication with the teacher $49.1 \%$ favorability $(35.5 \%$ Good, $13.6 \%$ Excellent) and in the case of response times associated with the delivery of results of the evaluation processes of the subjects, $63.1 \%$ of favorability is presented (44.3\% Good, $18.8 \%$ Excellent).

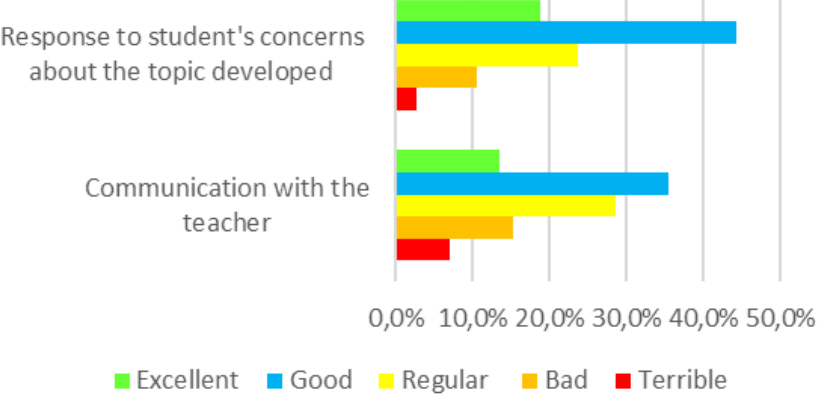

Fig. 7. Response of respondents on communication and accompaniment of teachers.

In general terms, although many higher education institutions in Colombia had virtual education programs, students within the framework of this emergency were not ready to assume the change of methodologies in their training processes. This is reflected in the fact that only $3 \%$ of the students prefer virtual education over face-to-face education, see Fig. 8.

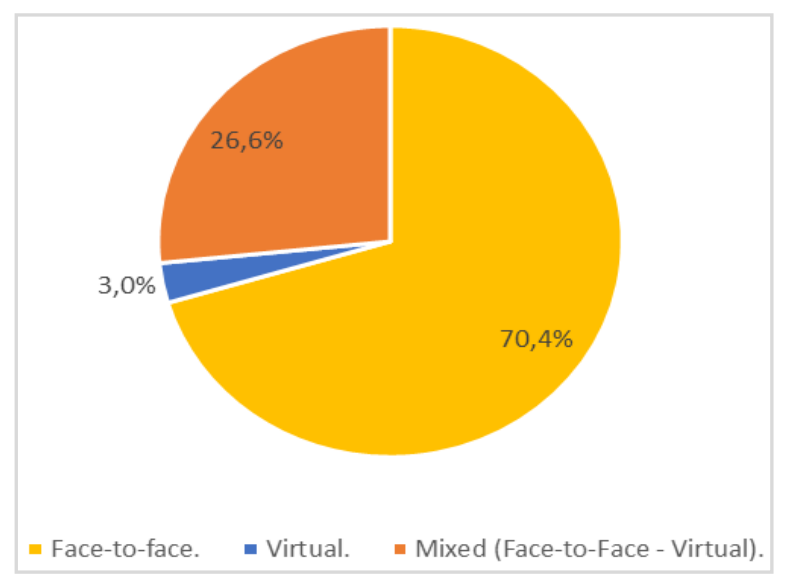

Fig. 8. Respondents' response to which mode of education they prefer.

\section{CONCLUSIONS}

The instrument applied made it possible to identify and contextualize the way in which higher education students from the Technology Faculty of the Universidad Distrital Francisco José de Caldas assumed the obligation of online classes during the quarantine established by the government authorities. It was possible to identify that a very high technological gap still exists with respect to access to an optimal broadband Internet 
connection, with only $10.5 \%$ of those surveyed being able to access it. In addition to this, it should be noted that on average such internet access is shared with 3 or 5 people simultaneously, see Table 2, increasing the limitations for most students taking their classes online.

With respect to teachers, the tool identified that students generally perceive a good process of communication and interaction in the online learning environment. With respect to communication, there was only a negative perception of $15.3 \%$ Bad and 7\% Terrible; compared to the response times of teachers, the negative perception was $10.5 \% \mathrm{Bad}$ and $2.7 \%$ Terrible. These percentages are directly linked to those students who perceived that the process of communication and interaction between teachers was not optimal, either due to failures in the technological infrastructure (equipment and internet access) or due to the lack of knowledge and skills associated with the online applications that were used for the teaching-learning process. This leads to rethinking training processes in digital tools for both teachers and students, in order to improve and increase the performance of these teaching methodologies.

\section{REFERENCES}

[1] Abuhassna, H., Zakaria, M., Yahya, N., Kosnin, A., \& Al-Rahmi, W. (2020). Examining students' satisfaction and learning autonomy through web-based courses. International Journal of Advanced Trends in Computer Science and Engineering, 9(1), 356-370.

[2] Aikina, T., \& Bolsunovskaya, L. (2020). Moodle-based learning: Motivating and demotivating factors. International Journal of Emerging Technologies in Learning, 15(2), 239-248.

[3] Azhari, F., Jasmi, N., Wahab, M., Jofrry, S., Lee, K., \& Ming, L. (2020). Students' perceptions about social constructivist learning environment in e-learning. Indian Journal of Pharmaceutical Education and Research, 54(2), 271-278.

[4] Connor, R., Travis, G., Peace, K., Propper, B., Hale, D., Alseidi, A., et al. (2020). Using technology to maintain the education of residents during the COVID-19 pandemic. Journal of Surgical Education, 77(4), 729732 .

[5] Ejubović, A., \& Puška, A. (2019). Impact of selfregulated learning on academic performance and satisfaction of students in the online environment. Knowledge Management and E-Learning, 11(3), 345363.

[6] Favale, T., Soro, F., Trevisan, M., Drago, I., \& Mellia, M. (2020). Campus traffic and e-learning during COVID-19 pandemic. Computer Networks, 176(1), 107290.

[7] Garcia, F., Corell, A., Abella, V., \& Grande, M. (2020). Online assessment in higher education in the time of covid-19. Education in the Knowledge Society, 21(1), 12.
[8] He, H., Zheng, Q., Di, D., \& Dong, B. (2019). How learner support services affect student engagement in online learning environments. IEEE Access, 7, 4996149973.

[9] Huang, R., Liu, D., Tlili, A., Yang, J., \& Wang, H. (2020). Handbook on facilitating flexible learning during educational discruption: The chinese experience in maintaning undisrupted learning in covid-19 outbreak. Online.

[10] Hussin, W., Harun, J., \& Shukor, N. (2019a). Online interaction in social learning environment towards critical thinking skill: A framework. Journal of Technology and Science Education, 9(1), 4-12.

[11] Hussin, W., Harun, J., \& Shukor, N. (2019b). A review on the classification of students' interaction in online social collaborative problem-based learning environment: How can we enhance the students' online interaction? Universal Journal of Educational Research, 7(9A), 125-134.

[12] Im, T., \& Kang, M. (2019). Structural relationships of factors which impact on learner achievement in online learning environment. International Review of Research in Open and Distance Learning, 20(1), 112-124.

[13] Israfilov, N., Borisova, O., Kartashova, O., Davydova, N., Biserova, G., \& Gryaznukhin, A. (2020). Motivation and employee effectiveness in online learning environments: Leadership strategies of new generation and emotional intellect. International Journal of Emerging Technologies in Learning, 15(9), 258-279.

[14] Mesiono, M. (2020). E-learning management of state islamic university of north sumatera in pandemic covid19. International Journal of Advanced Science and Technology, 29(5), 9573-9582.

[15] Mulenga, E., \& Marbán, J. (2020). Is COVID-19 the gateway for digital learning in mathematics education? Contemporary Educational Technology, 12(2), ep269.

[16] Muljana, P., \& Luo, T. (2019). Factors contributing to student retention in online learning and recommended strategies for improvement: A systematic literature review. Journal of Information Technology Education: Research, 18, 19-57.

[17] Ospina, Y., \& Galvis, J. (2017). A novel design of an Elearning digital ecosystem. Tekhnê, 14(1), 55-60.

[18] Starr-Glass, D. (2020). Encouraging engagement: videoconference augmentation of online distance learning environments. On the Horizon, ahead-of-print.

[19] Tikhomirov, V., Dneprovskaya, N., \& Yankovskaya, E. (2015). Three dimensions of smart education. In Recent research on smart education and e-learning (p. 47-53).

[20] Winarso, W., Yuliana, Y., Muniroh, L., Halin, H., \& Tyas, D. (2020). Changes in learning patterns during the pandemic covid-19; the case at university $\mathrm{x}$ in bekasi, west java, indonesia. International Journal of Advanced Science and Technology, 29(6), 8535-8539. 
International Journal of Engineering Research and Technology. ISSN 0974-3154, Volume 13, Number 8 (2020), pp. 1934-1939

(C) International Research Publication House. https://dx.doi.org/10.37624/IJERT/13.8.2020.1934-1939

[21] Wong, J., Baars, M., Davis, D., Van Der Zee, T., Houben, G., \& Paas, F. (2019). Supporting selfregulated learning in online learning environments and moocs: A systematic review. International Journal of Human-Computer Interaction, 35(4-5), 356-373.

[22] Zalli, M., Nordin, H., \& Hashim, R. (2020). Online selfregulated learning strategies in moocs: A measurement model. International Journal of Emerging Technologies in Learning, 15(8), 255-263. 